\title{
Implication des arts plastiques et des oeuvres d'art dans l'éducation du goût
}

\section{Francisca Lefort-Munoz}

\section{(2) OpenEdition \\ 1 Journals}

\section{Édition électronique}

URL : http://journals.openedition.org/trema/1930

DOI : 10.4000/trema.1930

ISSN : 2107-0997

\section{Éditeur}

Faculté d'Éducation de l'université de Montpellier

\section{Édition imprimée}

Date de publication : 1 avril 1997

Pagination : 55-68

ISSN : 1167-315X

\section{Référence électronique}

Francisca Lefort-Munoz, «Implication des arts plastiques et des oeuvres d'art dans l'éducation du goût », Tréma [En ligne], 11 | 1997, mis en ligne le 01 avril 1997, consulté le 19 avril 2019. URL : http:// journals.openedition.org/trema/1930 ; DOI : 10.4000/trema.1930

Ce document a été généré automatiquement le 19 avril 2019

Trema 


\section{Implication des arts plastiques et des oeuvres d'art dans l'øducation du goßt}

Francisca Lefort-Munoz

Dans les textes officiels les plusonresentsaiteligatiEcole de doter l'enfant

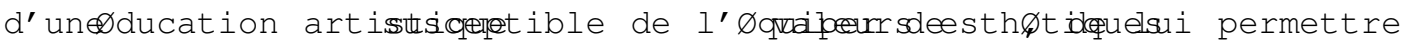

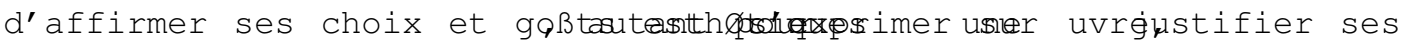

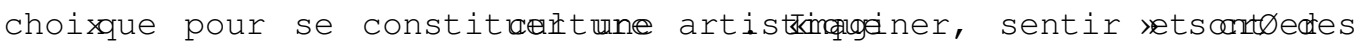
moyens dedonner un sens ses actions... ledcrivers...

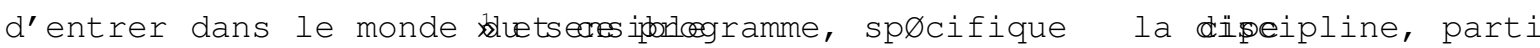
la construction de l'enfant.

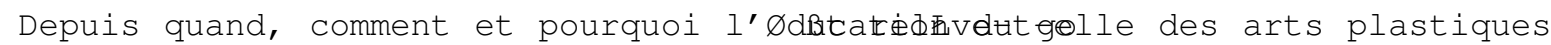
et de l'enseignement artistique ? Polrs appara t nØcessaire

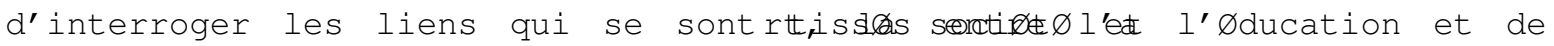
comprendre le poids de leurs implicturadrisonstarcthælim. C'est en 1972 que le terme « enseignement des arts plastiquesl rempkaeseignement du dessin ».

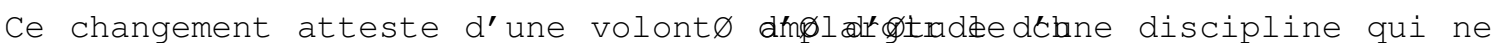
devint obligatoire qu'en 1833 pour l'squeiemaitres'introduisit en 1853

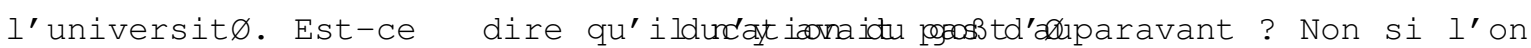

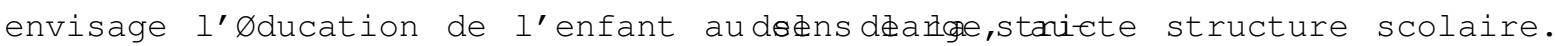
Mais il faudra d'embløe distinguer l'etasotigqemende al'enseignement esthøtique : Øduquer le futur artisteldould'homecomaisseur ? Pourquoi ? Comment? Quel r le l'art ou les a lotuenpovent'lihs cómme pour l'autre ?

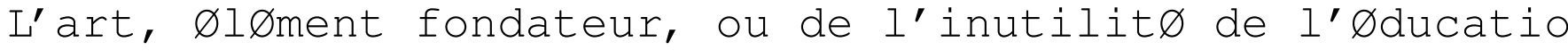
du goßt

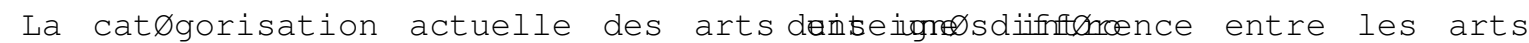
plastiques et les arts appliquØs, que foemabionpderl'artiste ou celle de la 









